\title{
Socio-economic Characteristics and Perception of the Lettuce Consumer
}

\author{
Janiquelle da S. Rabelo ${ }^{1}$, Patrícia Verônica P. S. Lima ${ }^{2}$, Marcelo de A. Guimarães ${ }^{1}$, Jean Paulo de J. Tello ${ }^{3}$, \\ Ana Régia A. de A. Hendges ${ }^{1}$, Bruno do N. Silva ${ }^{4}$, Benedito P. Lima Neto ${ }^{1} \&$ Caris dos S. Viana ${ }^{1}$ \\ ${ }^{1}$ Department of Plant Science, Center of Agrarian Sciences, Federal University of Ceará, Fortaleza, Ceará, \\ Brazil \\ ${ }^{2}$ Department Economy Agricultural, Center of Agrarian Sciences, Federal University of Ceará, Fortaleza, Ceará, \\ Brazil \\ ${ }^{3}$ Department of Plant Biology, Federal University of Viçosa, Viçosa, Mina Gerais, Brazil \\ ${ }^{4}$ Department of Plant Sciences, Federal University of Viçosa, Viçosa, Mina Gerais, Brazil \\ Correspondence: Janiquelle da S. Rabelo, Department of Plant Science, Center of Agrarian Sciences, Federal \\ University of Ceará, Fortaleza, Ceará, Brazil. Tel: (85)-987-134-426. E-mail: rabelojs@hotmail.com
}

Received: August 29, 2018

doi:10.5539/jas.v10n12p501
Accepted: October 2, $2018 \quad$ Online Published: November 15, 2018

URL: https://doi.org/10.5539/jas.v10n12p501

\begin{abstract}
Lettuce is the most consumed leaf vegetable in the world. Knowing the preferences and opinions of consumers of this important vegetable species can not only make the future availability of a better-quality product possible, but also redefine marketing methods and production in the field. The aim of this study was to evaluate the perception of lettuce consumers based on their socio-economic characteristics. Interviews with consumers were carried out to gather the information. The data found with the research showed that socio-economic characteristics such as gender, schooling, age and income do not significantly influence the perception of the lettuce consumer. The conclusion was therefore, that consumers make up a homogeneous group with similar behaviour patterns, characterising a market that is not very complex and is easily understood and accessed by producers, where there are no niches to be explored nor the need to differentiate the product to meet the needs of specific groups (men and women, young and old, people with more or less education or income).
\end{abstract}

Keywords: Lactuca sativa, market study, lettuce varieties

\section{Introduction}

In recent years, food consumption has undergone a series of transformations, with a growing demand from society for natural products (Hospido et al., 2009). These transformations result from the changing habits of the population in search of a better quality of life (Araujo, 2016). However, consumption of the principal natural foods (fruits, legumes and vegetables [FLV]) is still low. There is evidence that the consumption of these vegetables in Brazil is lower than that recommended by the World Health Organisation (WHO) (Campos, Bastos, Gauche, Boing, \& Assi, 2010; Francilino, Gondim, F. F. Silva, J. L. Silva, \& Y. A. Silva, 2014), i.e. it is less than five or more daily portions, the equivalent to around $400 \mathrm{~g} \mathrm{day}^{-1}$ (WHO, 2003).

According to Brasil (2015), the percentage of adults over 18 who consumed five or more portions of fruit and vegetables per day corresponded to $24.1 \%$ in 2014. In the case of lettuce, despite i) being the most-consumed leaf vegetable among Brazilians (Sediyama et al., 2016; Brzezinski, Abati, Geller, Wener, \& Zucareli, 2017), ii) presenting characteristics such as the presence of antioxidants, vitamins $\mathrm{C}$ and $\mathrm{E}$, carotenoids and a low calorie content (Nicolle et al., 2004; Afroj \& Rahman, 2016) and iii) the growing increase in production (Sala \& Costa, 2012), the consumption pattern is also small. Data published by the Brazilian Institute of Geography and Statistics (IBGE, 2011) in the Family Budget Survey of 2008-2009 show that per capita consumption of lettuce in Brazil is 3.6 $\mathrm{g} \mathrm{day}^{-1}$, whereas in the Northeast it is only $0.6 \mathrm{~g} \mathrm{day}^{-1}$. In this region, the prevalence of food consumption is only $2.4 \%$, while in the South it is $18.4 \%$.

In this scenario, strategies to stimulate lettuce consumption take on social and economic importance, whether due to reasons of nutrition and public health, or the fact that lettuce is cultivated mainly by family farmers (Sediyama et al., 2016; Brzezinski et al., 2017) and may contribute significantly to the composition of family 
income. In turn, such strategies require knowledge of consumer behaviour and preferences. However, most studies of lettuce prioritise productivity and technical aspects (Araújo, 2016), for example, by looking at the agronomic performance of cultivars (Seabra Junior et al., 2010) or systems of cultivation (Gualberto, Oliveira, \& Guimarães, 2009).

Knowledge of consumer behaviour is essential in any productive activity, since it provides elements useful to managers in the decision-making processes aimed at increasing sales. Identifying differences among consumers is also important, given that the socio-economic characteristics of the individual define food consumption and the purchase decision (Morven \& Minor, 2005). Darmon and Drewnowski (2008) identified a relationship between income and food choice. Dettmann and Dimitri (2009) on the other hand, concluded that schooling influenced a predisposition to consume healthy foods. It is therefore acceptable to suppose different patterns of consumption based on age, gender, schooling or income (Panzone, Hilton, Saule, \& Cohen, 2016).

From this perspective, a segmented analysis by consumer group favours more-detailed knowledge and the identification of possible market niches, both decisive factors in the decision-making processes that involve marketing. The aim of this article therefore, is to analyse whether the perception of lettuce consumers at the time of purchase is associated with their socio-economic characteristics.

\section{Method}

The present study was carried out in the city of Fortaleza in the State of Ceará, from 20 to 30 January 2014, by the Centre for Olericulture Studies of the Northeast (NEON), located in the Department of Plant Science of the Federal University of Ceará. The study employed survey research, which according to Freitas, Oliveira, Saccol and Moscarola (2000), consists in obtaining data on the characteristics and opinions of a group of people (lettuce consumers), generally by means of a questionnaire. This type of research is suitable when seeking to answer such questions as what, why, how and how much.

The criteria adopted for respondent eligibility in the sampling process were that they be a consumer of lettuce and over 18 years old. The method chosen was convenience sampling, in which participants were chosen because of their availability. The reasons that led to this choice of method were budget constraints on conducting the research and the need for working with a specific group of people, in this case lettuce consumers.

The sample size was defined as 120 consumers. According to Moscarola (1990), sample sizes of less than 30 observational units should be avoided, as this increases the chances of finding erroneous values. On the other hand, samples of 100 or more pieces of information tend to produce results that are closer to the reality under study.

The sample size was defined based on the following criteria: the availability of people to participate in the research, and the representativeness of the population (the city chosen for the research was divided into five regions, which were relatively homogeneous internally, but heterogeneous between themselves.)

To collect the information, interviews were conducted with consumers in five different types of produce market: 1) Hypermarket, 2) Neighbourhood shop (minimarket), 3) Street market, 4) Municipal Market (São Sebastião) and 5) CEASA-CE (Ceará Supply Centre). The questionnaire was applied in loco, as the people were choosing the lettuce. When preparing the questionnaire, the idea was to capture the behaviour of consumers at the time of purchase from factors associated with that behaviour, which according to Gains (1994) include i) the food itself (appearance, origin, etc), ii) personal characteristics (age, gender, schooling, income, etc) and iii) context (place of purchase, frequency of purchase, etc). Consequently, consumers were asked questions which were divided into two groups: socio-economic characteristics and consumer perception regarding the purchase and consumption of lettuce. Table 1 summarises the variables analysed in the research.

\subsection{Measures and Covariates}

A descriptive analysis of the perception variables was carried out employing the percentage distribution of respondents based on their socio-economic characteristics: gender, schooling, age and income. Graphs and contingency tables were prepared to present the results. The association between the variables representing the socio-economic characteristics and consumer perception was verified by means of Cramér's V coefficient, since the variables under analysis analyzed adopted both nominal and ordinal levels of measurement.

Cramér's V correlation coefficient is a measure of the association between two variables, and is indicated in cases where at least one of the variables is expressed on a nominal scale. According to Siegel and Castellan Jr. (2006), Cramér values vary between 0 (absence of association between the variables) and 1 (perfect association between variables). Values below 0.3 were considered a weak association and above 0.5 a strong association. In 
cases where the estimated coefficient had a level of significance below 0.05 , the association between the variables was considered statistically significant.

A descriptive analysis of the variable 'average time to perishability' (classified as quantitative) was carried out using mean values, and the difference between groups of consumers was verified by analysis of variance (ANOVA).

\section{Results}

\subsection{Socio-economic Characteristics of Consumers}

Analysis of the results relative to consumer perception at the time of purchase was guided by socio-economic characteristics. As can be seen, there is a segmentation among the 120 respondents, which, as pointed out in Figueiredo et al. (2008), may influence the decision to consume lettuce. The majority are females (74.6\%), which was expected, given that mainly women are responsible for purchasing food. The age group is relatively young, with only $17.5 \%$ of the respondents aged over 60 , being $43,9 \%$ between 20 and $40 ; 38,6 \%$ between 41 and 60 Most are married (76\%), with a complete secondary education and monthly family income of up to BRL 2000.00 .

The descriptive variables for the characteristics and perceptions of lettuce consumers were: Socioeconomic variables; Genre; Age; Income and schooling; Variables perceptions; Knowledge about the origin of the product; Absence of information as difficulty in choosing lettuce at the time of purchase; Knowledge about the cultivation system; More perishable variety; Frequency of lettuce consumption; Loss occurring before consumption; Preference as to the cultivation system used in the production of lettuce; Average time of perishability; Preference for lettuce variety; Treatment to avoid loss; Main criterion adopted in the purchase decision to pay for a minimally processed product.

\subsection{Perception of Lettuce Consumers Based on Their Socio-economic Characteristics}

As shown in Table 1, it was found that $55.4 \%$ of respondents were able to answer concerning the origin of the product they were purchasing. In this group, $27.5 \%$ gave the Supply Centre-CEASA - as the supplier. A comparison of the groups shows that knowledge of the origin of the product and of the system used in cultivating the lettuce does not depend on the age, schooling or income of the consumer. On the other hand, there is statistical evidence that men have a greater perception of the two variables.

Table 1. Perception of lettuce consumers as to the origin of the product and system of cultivation, based on socio-economic characteristics

\begin{tabular}{|c|c|c|c|c|c|}
\hline \multicolumn{2}{|r|}{ Socio-economic Characteristics } & \multicolumn{2}{|c|}{ Knowledge of the origin of the product } & \multicolumn{2}{|c|}{ Knowledge of the system of cultivation } \\
\hline Variable & Breakdown of the variable for class & $\%$ of YES answers & Cramér's V & $\%$ of YES answers & Cramér's V \\
\hline \multirow{2}{*}{ Gender } & Masculine & 75.9 & \multirow{2}{*}{$0.244^{*}$} & 96.6 & \multirow{2}{*}{$0.389^{*}$} \\
\hline & Feminine & 48.2 & & 54.8 & \\
\hline & Between 20 and 40 & 48.0 & & 66.0 & \\
\hline \multirow[t]{3}{*}{ Age } & Between 41 and 60 & 63.6 & 0.144 & 68.2 & 0.091 \\
\hline & Over 60 & 55.0 & & 57.9 & \\
\hline & Basic Education & 50.0 & & 59.3 & \\
\hline \multirow[t]{3}{*}{ Schooling } & Secondary Education & 52.3 & 0.156 & 66.2 & 0.096 \\
\hline & Higher Education & 71.4 & & 71.4 & \\
\hline & Below BRL 1000.00 & 57.1 & & 76.2 & \\
\hline \multirow[t]{2}{*}{ Monthly Income } & Between BRL 1000.00 and BRL 2000.00 & 54.0 & 0.041 & 55.1 & 0.190 \\
\hline & Over BRL 2000.00 & 55.8 & & 65.5 & \\
\hline \multicolumn{2}{|l|}{ Total Sample } & 55.4 & & 65.2 & \\
\hline
\end{tabular}

Note. *Significant association between groups at a level of $1 \%$.

Source: Prepared by the author from field research data.

Lettuce has great market potential, taking into account the low per capita consumption. Even among current consumers there is room for expansion, considering that $54.5 \%$ of respondents said they only purchased the leaf vegetable once a week. The segmented analysis (Figure 1) pointed out that gender, age, schooling and income 
are not significantly associated with the frequency of lettuce consumption. This trend differs from the more general analyses that include the expanded market of fruit, legumes and vegetables (FLV).
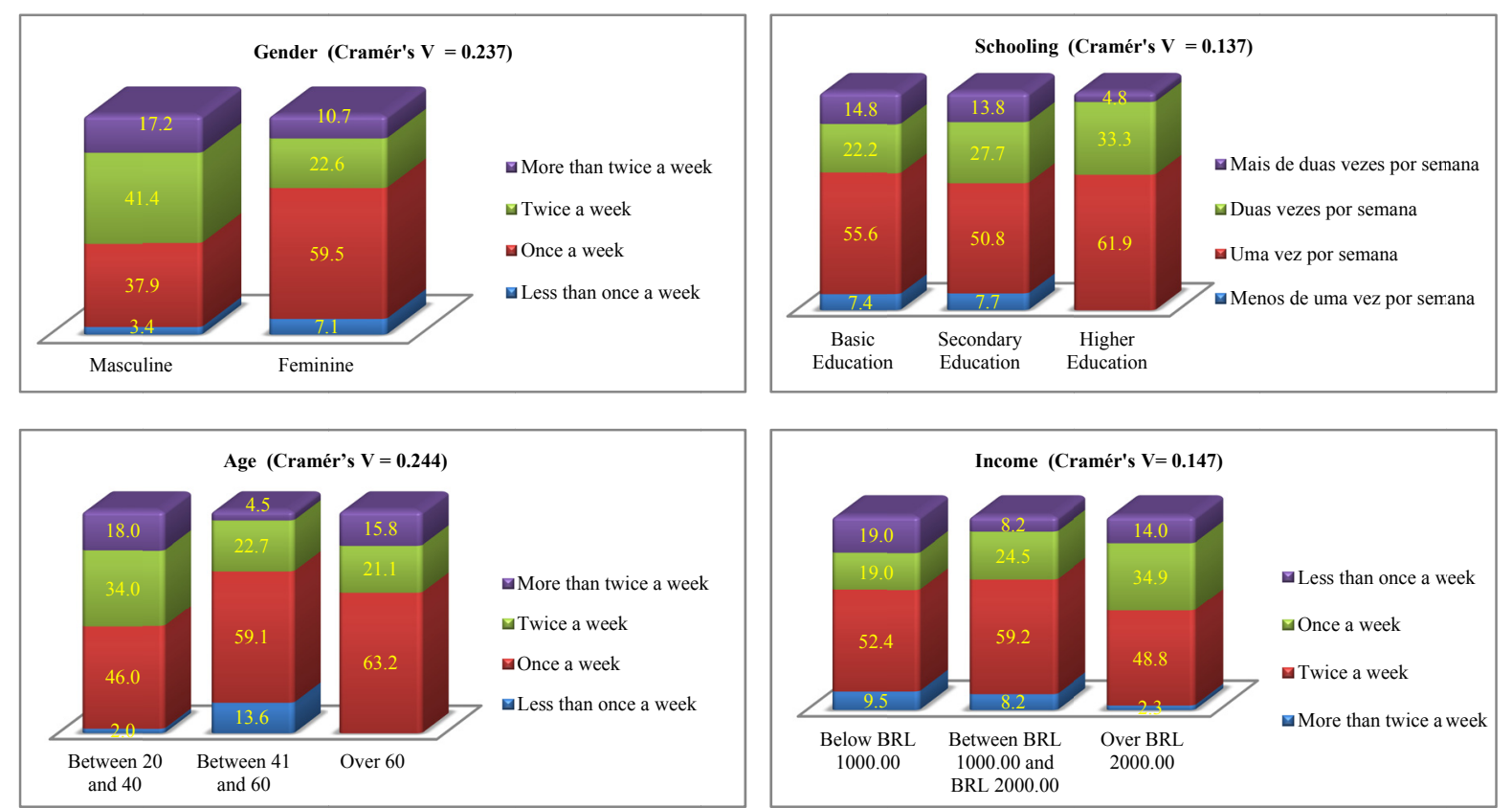

Figure 1. Frequency of lettuce consumption based on the socio-economic characteristics of the consumers Note. $*$ Significant association between groups at a level of $1 \% ; *$ Significant association between groups at a level of $5 \%$.

When asked about their preference for the system of cultivation of the lettuce they consumed, $53.6 \%$ of people chose the conventional system (soil), another $21.4 \%$ preferred hydroponically produced lettuce, and only $9.8 \%$ chose the product of an organic environment. Those who opted for hydroponically produced lettuce gave the hygiene of the purchased product as the main advantage. On the other hand, although the consumers of lettuce produced under the organic system found the product to be healthier, they all said that organic lettuce had a shorter shelf life compared to non-organic lettuce, with $75.4 \%$ being willing to pay more for the organic product. In addition, $15.2 \%$ of the respondents had no opinion on preference. In Figure 2, it can be seen that there is no significant association between preference for a system of cultivation and the socio-economic characteristics of the consumers. 

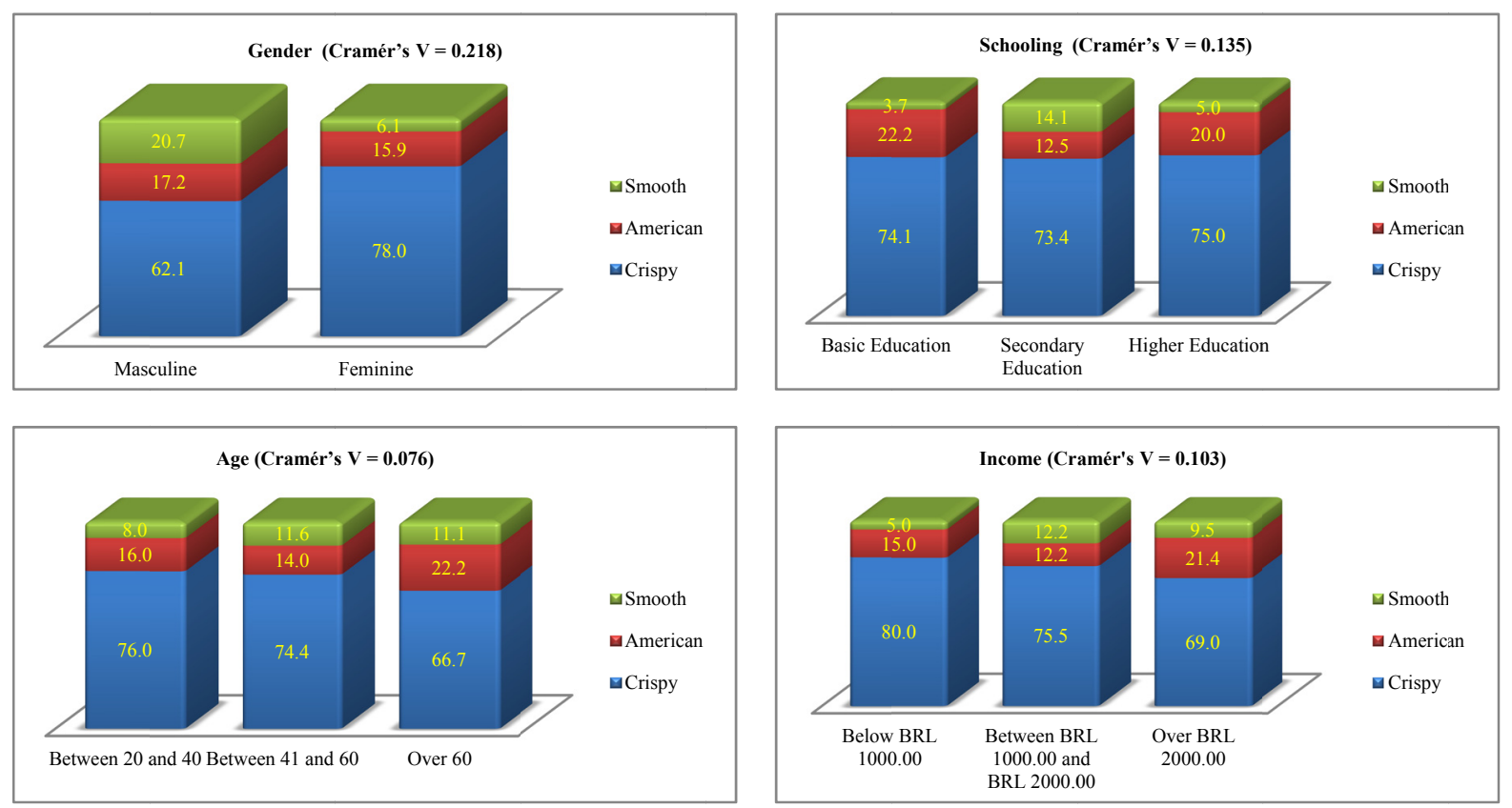

Figure 2. Consumer preference for lettuce variety based on socio-economic characteristics

Note. * Significant association between groups at a level of $1 \% ; * *$ Significant association between groups at a level of $5 \%$.

Source: Prepared by the author from field research data.

The principal criterion taken into account when purchasing lettuce proved to be price, the determining factor for the largest class of consumers, followed by flavour and texture (Table 2). Analysis of purchasing criteria based on the socio-economic characteristics of the consumers showed that only age has a significant influence on the determining factor of the purchase, with older people valuing the quality of the lettuce, while younger people prioritise price.

Table 2. Perception of lettuce consumers at the time of purchase, based on socio-economic characteristics

\begin{tabular}{|c|c|c|c|c|c|c|c|}
\hline \multirow{2}{*}{\multicolumn{2}{|c|}{ Socio-economic Characteristics }} & \multicolumn{6}{|c|}{ Main criterion adopted in the purchase decision (\% of YES) } \\
\hline & & \multirow{2}{*}{$\begin{array}{l}\text { Texture } \\
34.5\end{array}$} & \multirow{2}{*}{$\begin{array}{l}\text { Taste } \\
17.2\end{array}$} & \multirow{2}{*}{$\begin{array}{l}\text { Price } \\
27.6\end{array}$} & \multirow{2}{*}{$\begin{array}{l}\text { Quality } \\
20.7\end{array}$} & \multirow{2}{*}{$\begin{array}{l}\text { Colour } \\
0.0\end{array}$} & \multirow{3}{*}{$\begin{array}{l}\text { Cramér's V } \\
0.333\end{array}$} \\
\hline Condo & Masculine & & & & & & \\
\hline Gender & Feminine & 14.1 & 21.2 & 36.5 & 10.6 & 17.6 & \\
\hline & Between 20 and 40 & 18.0 & 18.0 & 34.0 & 10.0 & 20.0 & \\
\hline \multirow[t]{3}{*}{ Age } & Between 41 and 60 & 22.7 & 27.3 & 40.9 & 2.3 & 6.8 & $0.342 *$ \\
\hline & Over 60 & 15.0 & 10.0 & 20.0 & 45.0 & 10.0 & \\
\hline & Basic Education & 17.9 & 14.3 & 35.7 & 21.4 & 10.7 & \\
\hline \multirow[t]{3}{*}{ Schooling } & Secondary Education & 21.5 & 20.0 & 35.4 & 7.7 & 15.4 & 0.150 \\
\hline & Higher Education & 14.3 & 28.6 & 28.6 & 19.0 & 9.5 & \\
\hline & BelowBRL 1000.00 & 23.8 & 24.0 & 38.1 & 19.0 & 14.3 & \\
\hline \multirow[t]{2}{*}{ Monthly Income } & BetweenBRL 1000.00 and BRL 2000.00 & 18.0 & 23.3 & 42.0 & 10.0 & 6.0 & 0.232 \\
\hline & Over BRL 2000.00 & 18.6 & 20.2 & 23.3 & 14.0 & 20.9 & \\
\hline Total Sample & & 19.6 & 20.5 & 33.9 & 12.5 & 13.5 & - \\
\hline
\end{tabular}

Note. *Significant association between groups at a level of $1 \%$.

Source: Prepared by the author from field research data. 
Although there is a growing trend for the consumption of pre-processed and packaged lettuce (Sala \& Costa, 2012), it was noted that in each strata of consumers only a minority was willing to pay more for any type of processing (Table 3). An alternative way of informing the consumer about important characteristics of the lettuce on display would be signs specifying origin, date of harvest, variety, etc.

Table 3. Consumer perception of the information available on packaging and the willingness to pay for a minimally processed product, based on socio-economic characteristics

\begin{tabular}{|c|c|c|c|c|c|}
\hline \multicolumn{2}{|c|}{ Socio-economic Characteristics } & \multicolumn{2}{|c|}{$\begin{array}{l}\text { Absence of information as a difficulty in } \\
\text { choosing lettuce at the time of purchase }\end{array}$} & \multicolumn{2}{|c|}{$\begin{array}{l}\text { Willingness to pay for a } \\
\text { minimally processed product }\end{array}$} \\
\hline & & (\% of YES) & Cramér's V & (\% of YES) & Cramér's V \\
\hline \multirow{3}{*}{ Gender } & Masculine & 51.7 & \multirow{2}{*}{0.109} & 27.6 & \multirow{2}{*}{0.121} \\
\hline & Feminine & 63.1 & & 41.0 & \\
\hline & Between 20 and 40 & 66.0 & & 44.0 & \\
\hline \multirow[t]{3}{*}{ Age } & Between 41 and 60 & 50.0 & 0.182 & 29.5 & 0.137 \\
\hline & Over 60 & 68.4 & & 38.9 & \\
\hline & Basic Education & 55.6 & & 34.6 & \\
\hline \multirow[t]{3}{*}{ Schooling } & Secondary Education & 60.0 & 0.062 & 38.5 & 0.033 \\
\hline & Higher Education & 66.7 & & 38.1 & \\
\hline & Below BRL 1000.00 & 57.1 & & 38.1 & \\
\hline \multirow[t]{2}{*}{ Monthly Income } & Between BRL 1000.00 and BRL 2000.00 & 63.3 & 0.049 & 32.7 & 0.095 \\
\hline & Over BRL 2000.00 & 58.1 & & 42.9 & \\
\hline \multicolumn{2}{|l|}{ Total Sample } & 60.7 & & 37.5 & \\
\hline
\end{tabular}

Note. *Significant association between groups at a level of $1 \%$.

Source: Prepared by the author from field research data.

Simple treatment, such as keeping the lettuce in a refrigerated environment and a closed container or bag, contribute to the leaf vegetable remaining fresh for longer. However, taking action to prevent loss before consumption is acknowledged by only $59.8 \%$ of respondents (Table 4 ). In this respect, it was noted that higher income levels are associated with the adoption of some type of loss prevention treatment, as can be seen by Cramér's V coefficient, which is significant at 5\%.

Table 4. Consumer perception of lettuce perishability and treatment for loss prevention, based on socio-economic characteristics

\begin{tabular}{|c|c|c|c|c|c|}
\hline \multicolumn{2}{|c|}{ Socio-economic Characteristics } & \multicolumn{2}{|c|}{$\begin{array}{l}\text { Loss occurring } \\
\text { before consumption }\end{array}$} & \multicolumn{2}{|c|}{$\begin{array}{l}\text { Treatment carried } \\
\text { out to prevent loss }\end{array}$} \\
\hline & & (\% of YES) & Cramér's V & ( $\%$ of YES) & Cramér's V \\
\hline \multirow{2}{*}{ Gender } & Masculine & 48.3 & \multirow{2}{*}{0.054} & 58.6 & \multirow{2}{*}{0.014} \\
\hline & Feminine & 42.2 & & 60.2 & \\
\hline \multirow{3}{*}{ Age } & Between 20 and 40 & 46.0 & & 60.0 & \multirow{3}{*}{0.122} \\
\hline & Between 41 and 60 & 34.1 & 0.188 & 54.5 & \\
\hline & Over 60 & 61.1 & & 72.2 & \\
\hline \multirow{3}{*}{ Schooling } & Basic Education & 61.5 & & 50.0 & \multirow{3}{*}{0.215} \\
\hline & Secondary Education & 38.5 & 0.197 & 56.9 & \\
\hline & Higher Education & 38.1 & & 81.0 & \\
\hline \multirow{3}{*}{ Monthly Income } & Below BRL 1000.00 & 47.6 & & 47.6 & \multirow{3}{*}{$0.296^{*}$} \\
\hline & Between BRL 1000.00 and BRL 2000.00 & 40.8 & 0.055 & 49.0 & \\
\hline & Over BRL 2000.00 & 45.2 & & 78.6 & \\
\hline \multicolumn{2}{|l|}{ Total Sample } & 43.8 & & 59.8 & \\
\hline
\end{tabular}

Note. *Significant association between groups at a level of $1 \%$.

Source: Prepared by the author from field research data. 
As for consumer perception of the time that lettuce takes to spoil, on average, consumers reported losing at least part of the product four days after purchase (Table 5). This is less than the time identified by Hospido et al. (2009), who found the average time to be seven days.

Table 5. Average time for lettuce loss after purchase, based on socio-economic characteristics

\begin{tabular}{|c|c|c|c|}
\hline \multicolumn{2}{|c|}{ Socio-economic Characteristics } & \multirow{3}{*}{$\begin{array}{l}\text { Number of days } \\
3.2 \\
4.2\end{array}$} & \multirow{3}{*}{$\begin{array}{l}\text { ANOVA F Statistic } \\
3.650 * * *\end{array}$} \\
\hline \multirow{2}{*}{ Gender } & Masculine & & \\
\hline & Feminine & & \\
\hline \multirow{3}{*}{ Age } & Between 20 and 40 & 3.8 & \\
\hline & Between 41 and 60 & 3.9 & 0.110 \\
\hline & Over 60 & 4.1 & \\
\hline \multirow{3}{*}{ Schooling } & Basic Education & 3.5 & \\
\hline & Secondary Education & 3.9 & 2.086 \\
\hline & Higher Education & 4.8 & \\
\hline \multirow{3}{*}{ Monthly Income } & Below BRL 1000.00 & 3.4 & \\
\hline & Between BRL 1000.00 and BRL 2000.00 & 4.0 & 0.420 \\
\hline & Over BRL 2000.00 & 3.9 & \\
\hline \multicolumn{2}{|l|}{ Total Sample } & 3.9 & - \\
\hline
\end{tabular}

Note. *** Significant difference between groups at a level of $10 \%$.

Source: Prepared by the author from field research data.

Further with regard to perishability, the crispy variety is noted as being the most perishable by $67.3 \%$ of all those interviewed, with $23.6 \%$ unsure (Table 6). However, this result does not necessarily accurately portray which of the varieties is the most perishable, and may be related to the greater consumption of the crispy variety. As in other areas under analysis, age, schooling and gender do not significantly influence consumer perception of the most perishable variety. However, men classify the crispy variety as the most perishable with a statistically greater frequency than do women.

Table 6. Consumer perception of the perishability of lettuce, based on socio-economic characteristics

\begin{tabular}{|c|c|c|c|c|c|c|}
\hline \multirow{2}{*}{\multicolumn{2}{|c|}{ Socio-economic Characteristics }} & \multicolumn{5}{|c|}{ Most perishable variety ( $\%$ of YES) } \\
\hline & & \multirow{2}{*}{$\begin{array}{l}\text { Crispy } \\
75.0\end{array}$} & \multirow{2}{*}{$\begin{array}{l}\text { American } \\
3.6\end{array}$} & \multirow{2}{*}{$\begin{array}{l}\text { Smooth } \\
7.1\end{array}$} & \multirow{3}{*}{$\begin{array}{l}\text { Unsure } \\
14.3 \\
26.5\end{array}$} & \multirow{3}{*}{$\begin{array}{l}\text { Cramér's V } \\
0.273^{* *}\end{array}$} \\
\hline & Masculine & & & & & \\
\hline Gender & Feminine & 65.1 & 8.4 & 0.0 & & \\
\hline \multirow{3}{*}{ Age } & Between 20 and 40 & 56.3 & 10.4 & 2.1 & 31.3 & \\
\hline & Between 41 and 60 & 77.3 & 2.3 & 2.3 & 18.1 & 0.174 \\
\hline & Over 60 & 73.7 & 10.5 & 0.0 & 15.8 & \\
\hline \multirow{3}{*}{ Schooling } & Basic Education & 57.7 & 3.8 & 0.0 & 38.5 & \\
\hline & Secondary Education & 65.6 & 9.4 & 3.1 & 21.9 & 0.192 \\
\hline & Higher Education & 85.7 & 4.8 & 0.0 & 9.5 & \\
\hline \multirow{3}{*}{ Monthly Income } & Below BRL 1000.00 & 76.2 & 9.5 & 0.0 & 14.3 & \\
\hline & Between BRL 1000.00 and BRL 2000.00 & 64.6 & 2.1 & 4.2 & 29.2 & 0.185 \\
\hline & Over BRL 2000.00 & 66.7 & 11.9 & 0.0 & 21.4 & \\
\hline \multicolumn{2}{|l|}{ Total Sample } & 67.3 & 7.3 & 1.8 & 23.6 & - \\
\hline
\end{tabular}

Note. **Significant association between groups at a level of $5 \%$.

Source: Prepared by the author from field research data.

\section{Discussion}

It can be seen that the segmentation captures the main socio-economic characteristics of the consumer: age, gender, schooling and income. From this it was possible to describe consumer perceptions regarding key aspects 
of the lettuce market: i) perception of the origin of the product, ii) consumption preferences iii) consumer perceptions at the time of purchase, and iv) perception of perishability.

Few studies of consumer behaviour emphasise the differences between consumers (Table 1). This is a theoretical limitation, since it is known that differences between genders, age groups, levels of schooling and income determine perceptions and attitudes (Kotler, 1998), and can therefore influence product consumption positively or negatively. The results presented below consequently seek a less reductionist method of studying the perception of lettuce consumers.

Studies as shown in Table 1 of this category of foods identified a higher frequency of consumption among women (Figueiredo et al., 2008), among older people (Pearson, Russel, Campbell, \& Barker, 2005), among those with a higher level of schooling (Jaime \& Monteiro, 2005; Thompson et al., 2005), and with higher incomes (Duran, Roux, Latorre, \& Jaime, 2013).

Among the varieties of lettuce available on the market, consumers said they preferred crispy lettuce $(73.6 \%)$. This result is similar to that presented by Sala and Costa (2012), who identified the crispy, American, smooth and romaine varieties, in that order, as the most sold in Brazil. These authors highlight the growth of American lettuce in the market; however, as shown in Figure 3, consumption is effectively still not widespread. The higher price of American lettuce is pointed to as one of the factors to explain this situation. However, consumption of this variety is low even among consumers with greater purchasing power. Although a larger proportion of consumers who prefer American lettuce can be seen at the higher levels of schooling, age and income, inferential analysis shows that a preference for one variety is not statistically associated with the socio-economic characteristics of the consumer.

The results obtained in this study (Table 2) are different from those obtained by Souza et al. (2008), who studied the purchasing behaviour of vegetable consumers in the State of Rio Grande do Sul, and found that quality, taste, price and texture, in that order, were the main factors looked for at the time of purchase. Quality proved to be less relevant among those interviewed, which contradicts studies of the purchase decision for vegetables in general (Andreuccetti, Ferreira, \& Tavares, 2005; Souza Neta et al., 2013) and strengthens the argument of Owen, Griffith, and Wright (2002), who maintain that the price elasticity of demand for fruits and vegetables favours price fluctuations, and strongly affects consumption of these products.

Lettuce is usually marketed 'in natura', with packaging showing no labels or information, and without any type of processing (Moretti \& Mattos, 2006; Chitarra \& Chitarra, 2007). This fact however does not necessarily indicate a consumer preference, given that the majority of respondents, regardless of their socio-economic characteristics, believe that the lack of information makes it difficult to choose leaf vegetables at the time of purchase (Table 3). Product information is usually given on the packaging in which the product is sold, which requires processing, albeit minimal, with a consequent increase in marketing costs and the final price of the product.

Lettuce is highly perishable, with low resistance to transport (Silva, Bezerra Neto, Negreiros, \& Pedrosa, 2000). This reflects in consumer perception of losses. As shown in Table 4, 43.8\% of the total interviewed reported loss of the product before consumption. This is a weakness noted by all segments of consumers irrespective of socio-economic characteristics, although it is possible to identify a higher frequency (although not significantly higher) among older consumers and those with less schooling.

This loss may be related to the way the product is stored by the consumer, since the majority of lettuces are susceptible to dehydration and damage, and display fragile physical characteristics, which may represent the rapid senescence of the product (Calbo, 2013).

A comparison of socio-economic segments shows that there is a significant difference between men and women in this aspect of lettuce consumption, and that women are able to keep lettuce suitable for consumption for longer periods (Table 5).

According to Sun and Zheng (2006), the problem of loss of perishable food can be reduced by modern techniques of refrigeration and cold storage, which can extend the shelf life of lettuce from three days to a few weeks.

The study showed that the consumer market for lettuce is location specific, highlighting the low frequency of consumption, the preference for the crispy variety, the importance of price at the time of purchase, and the small possibility of paying more for a minimally processed product. In general, there is no statistically significant association between the socio-economic characteristics and the perception of lettuce consumers. One implication of this is that consumers make up a homogeneous group, with similar perceptions and interests, characterising a 
market that is not very complex and is easily understood and accessed by producers, where there are no niches to be explored nor the need to differentiate the product to meet the needs of specific groups (men and women, young and old, people with more or less education or income).

\section{References}

Afroj, M., \& Rahman, M. M. (2016). Consumer knowledge and marketof lettuce in Dhaka city. SAARC Journal of Agriculture, 14, 145-150. https://doi.org/10.3329/sja.v14i1.29584

Andreuccetti, C., Ferreira, M. D., \& Tavares, M. (2005). Perfil dos compradores de tomate de mesa em supermercados da região de Campinas. Horticultura Brasileira, 23, 148-153. https://doi.org/10.1590/ S0102-05362005000100031

Araujo, R. R. (2016). Atribuição de julgamento e significado noconsumo de frutas, legumes e verduras orgânicos (Thesis, University of Brasília, Brasília, Brazil). Retrieved from http://bdm.unb.br/handle/ $10483 / 16080$

Brzezinski, C. R., Abati, J., Geller, A., Werner, F., \& Zucareli, C. (2017). Produção de cultivares de alface americana sob dois sistemas de cultivo. Revista Ceres, 64, 83-89. https://doi.org/10.1590/0034-737x2017 64010012

Calbo, A. G. (1999). Alface. Brasília: Embrapa Hortaliças. Retrieved from http://www.cnph.embrapa.br/laborato/ pos_colheita/ alface.htm

Campos, V. C., Bastos, J. L., Gauche, H., Boing, A. F., \& Assis, M. A. A. (2010). Fatores associados ao consumo adequado de frutas, legumes e verduras em adultos de Florianópolis. Revista Brasileira Epidemiologia, 13, 352-362. https://doi.org/10.1590/S1415-790X2010000200016

Chitarra, M. I. F., \& Chitarra, A. B. (2007). Processamento mínimo de alface. In C. L. Moretti (Ed.), Manual de Processamento Mínimo de Frutas e Hortaliças (pp. 299-342). Brasília, DF: SEBRAE.

Darmon, N., \& Drewnowsk, A. (2008). Does social class predict diet quality? The American Journal of Clinical Nutrition, 87, 1107-1117. https://doi.org/10.1093/ajcn/87.5.1107

Dettmann, R. L., \& Dimitri, C. (2009). Who's buying organic vegetables? Demographic characteristics of U.S. consumers. Journal of Food Products Marketing, 16, 79-91. https://doi.org/10.1080/10454440903415709

Duran, A. C., Roux, A. V. D., Latorre, M. R. D. O., \& Jaime, P. C. (2013). Neighborhood socioeconomic characteristics and differences in the availability of healthy food stores and restaurants in Sao Paulo, Brazil. Health \& Place, 23, 39-47. https://doi.org/10.1016/j.healthplace.2013.05.001

Figueiredo, I. C. R., Jaime, P. C., \& Monteiro, C. A. (2008). Fatores associados ao consumo de frutas, legumes e verduras em adultos da cidade de São Paulo. Revista de Saúde Pública, 42, 777-785. https://doi.org/ $10.1590 / \mathrm{S} 0034-89102008000500001$

Francilino, A. H., Gondim, A. R. O., Silva, F. F., Silva, J. L. B., \& Silva, Y. A. (2014). Perfil dos consumos de hortaliças no município de Iguatu-CE. Revista Verde de Agroecologia e Desenvolvimento Sustentável, 9, $120-126$.

Freitas, H., Oliveira, M., Saccol, A. Z., \& Moscarola, J. (2000). O método de pesquisa survey. Revista de Administração, 35, 105-112.

Gains, N. (1994). The repertory grid approach. In H. J. H. Macfie, \& D. M. H. Thomson (Eds.), Measurement of food preference (pp. 51-76).

Gualberto, R., Oliveira, P. S. R., \& Guimarães, A. M. (2009). Adaptabilidade e estabilidade fenotípica de cultivares de alface do grupo crespa em cultivo hidropônico. Horticultura Brasileira, 27, 7-11. https://doi.org/10.1590/S0102-05362009000100002

Hospido, A., Canals, L. M. I., McLaren, S., Truninger, M., Edwards-Jones, G., \& Clift, R. (2009). The role of seasonality in lettuce consumption: A case study of environmental and social aspects. The Internacional Jornal Life Cycle Assessment, 14, 381-391. https://doi.org/10.1007/s11367-009-0091-7

IBGE (Instituto Brasileiro de Geografia e Estatística). (2011). Pesquisa de orçamentos familiares 2008-2009: Análise do consumo alimentar pessoal no Brasil. Rio de Janeiro, RJ: IBGE.

Jaime, P. C., \& Monteiro, C. A. (2005). Fruit and vegetable intake by Brazilian adults, 2003. Cadernos de Saúde Pública, 21(Suppl. 1), S19-S24. https://doi.org/10.1590/S0102-311X2005000700003

Kotler, P. (1998). Administração de marketing (5nd ed.). São Paulo, SP: Atlas. 
Ministério da Saúde. (2015). Vigitel Brasil 2014: Vigilância de fatores de risco e proteção para doenças crônicas por inquérito telefônico. Brasília, DF: Ministério da Saúde.

Moretti, C. L., \& Mattos, L. M. (2006). Processamento mínimo de alface crespa. Technical Communication (Vol. 36, pp. 1-7). Brasília, DF: Embrapa Hortaliças.

Moscarola, J. (1990). Enquêtese tanalyse de données. Paris: Vuibert.

Nicolle, C., Cardinault, N., Gueux, E., Jaffrelo, L., Rock, E., Mazur, A., ... Rémésy, C. (2004). Health effect of vegetable-based diet: Lettuce consumption improves cholesterol metabolism and antioxidant status in the rat. Clinical Nutrition, 23, 605-614. https://doi.org/10.1016/j.clnu.2003.10.009

Owen, K. M., Griffith, G. R., \& Wright, V. E. (2002). One little Lebanese cucumber is not going to break the bank: Price in the choice of fresh fruits and vegetables. The Australian Journal of Agricultural and Resource Economics, 46, 209-231. https://doi.org/10.1111/1467-8489.00026

Panzone, L., Hilton, D., Saule, L., \& Cohen, D. (2016). Socio-demographics, implicit attitudes, explicit attitudes, and sustainable consumption in supermarket shopping. Journal of Economic Psychology, 55, 77-95. https://doi.org/ 10.1016/j.joep.2016.02.004

Pearson, T., Russell, J., Campbell, M. J., \& Barker, M. E. (2005). Do “food deserts" influence fruit and vegetable consumption?-A cross-sectional study. Appetite, 45, 195-197. https://doi.org/10.1016/j.appet.2005.04.003

Sala, F. C., \& Costa, C. P. (2012). Retrospectiva e tendência da alfacicultura brasileira. Horticultura Brasileira, 30, 187-194. https://doi.org/10.1590/S0102-05362012000200002

Seabra Junior, S., Souza, S. B. S., Neves, L. G., Theodoro, V. C. A., Nunes, M. C. M., Nascimento, A. S., ... Leão, L. L. (2010). Desempenho de cultivares de alface tipo crespa sob diferentes telas de sombreamento no período de inverno. Horticultura Brasileira, 28, 252-259.

Sediyama, M. A. N., Magalhães, I. P. B., Vidigal, S. M., Pinto, C. L. O., Cardoso, D. S. C. P., Fonseca, M C. M., \& Carvalho, I. P. L. (2016). Uso de fertilizantes orgânicos no cultivo de alface americana (Lactuca sativa L.) 'Kaiser'. Revista Brasileira de Agropecuária Sustentável, 6. https://doi.org/10.21206/rbas.v6i2.308

Siegel, S., \& Castellan Jr., N. J. (2006). Medidas de associação e seus testes de significância. Estatística não-paramétrica para ciências do comportamento (2nd ed., pp. 255-346). Porto Alegre, RS: Artmed.

Silva, V. F., Bezerra Neto, F., Negreiros, M. Z., \& Pedrosa, J. F. (2000). Comportamento de cultivares de alface em diferentes espaçamentos sob temperatura e luminosidade elevadas. Horticultura Brasileira, 18, 183-187. https://doi.org/10.1590/S0102-05362000000300008

Souza Neta, M. L., Silva, R. T., Souza, A. A. T., Pamplona, J. P., Oliveira, F. A., \& Oliveira, M. K. T. (2013). Perfil dos consumidores de hortaliças do município de Apodi-RN. Agropecuária Científica no Semiárido, 9, $50-56$.

Souza, R. S., Arbage, A. P., Neumanni, P. S., Froehlich, M. J., Diese, V., Silveira, P. R.,... Lisboa, R. S. A. (2008). Comportamento de compra dos consumidores de frutas, legumes e verduras na região central do Rio Grande do Sul. Ciência Rural, 38, 511-517. https://doi.org/10.1590/S0103-84782008000200034

Sun, D. W., \& Zheng, L. (2006). Vacuum cooling technology for the agri-food industry: Past, present and future. Journal of Food Engineering, 77, 203-214. https://doi.org/10.1016/j.jfoodeng.2005.06.023

Thompson, F. E., Midthune, D., Subar, A. F., McNeel, T., Berrigan, D., \& Kipnis, V. (2005). Dietary intake estimates in the national health interview survey, 2000: Methodology, results and interpretation. Journal of the American Dietetic Association, 105, 352-363. https://doi.org/10.1016/j.jada.2004.12.032

WHO (World Health Organization). (2003). Diet, nutrition and the prevention chronic diseases. Geneva: WHO.

\section{Copyrights}

Copyright for this article is retained by the author(s), with first publication rights granted to the journal.

This is an open-access article distributed under the terms and conditions of the Creative Commons Attribution license (http://creativecommons.org/licenses/by/4.0/). 